\title{
ADOPSI INOVASI MEDIA KOMUNIKASI-INFORMASI-EDUKASI (KIE) UNTUK MENGUATKAN INDUSTRI KREATIF KOTA PEKALONGAN DI ERA INDUSTRI 4.0
}

\author{
Mohammad Reza Maulana ${ }^{*}$, Bambang Ismanto, Hari Agung Budijanto, Sattriedi Wahyu Binabar \\ STMIK Widya Pratama Pekalongan \\ J1 Patriot No 25 Pekalongan Telpon (0285) 427816,
}

Korespondensi : reza.stmikwp@gmail.com

\begin{abstract}
One of the real sectors that currently gets priority from the government is the creative economy, this can be seen by the formation of a special body that is responsible for promoting creative economic growth in Indonesia, through Presidential Regulation of the Republic of Indonesia Number 6 Year 2015 concerning the Creative Economy Agency, the Creative Economy Agency (Bekraf), but based on the submission of the Governor of Bank Indonesia (BI) Agus Martowardojo at the exhibition of BIassisted MSMEs at Balai Kartini, Jakarta, Friday (8/26/2016), there could be 3, three Indonesians, namely: limited access to credit, creative industries too do not have broad access to international markets, limited human resources and skills. This research aims to realize a communicationinformation-education media that synergizes government institutions, financial institutions, research institutions and creative industries, so as to facilitate the creative industry players to obtain various things needed for development, can help, and improve their positivity, thus increasing the industry creative to be more competitive in the industrial era 4.0.
\end{abstract}

Keywords: Creative industries, Communication-information-education media, Synergizing.

\section{PENDAhUluan}

Ekonomi kreatif merupakan upaya pembangunan ekonomi secara berkelanjutan melalui kreatifivas. Ini merupakan salah satu sektor riil yang saat ini mendapatkan prioritas dari pemerintah adalah ekonomi kreatif, ini terlihat dengan dibentukannya suatu badan khusus yang bertanggung jawab untuk mendorong pertumbuhan ekonomi kreatif di Indonesia, melalui Peraturan Presiden Republik Indonesia Nomor 6 Tahun 2015 Tentang Badan Ekonomi Kreatif, Badan Ekonomi Kreatif (Bekraf).

Berdasarkan penyampaian Gubernur Bank Indonesia (BI) Agus Martowardojo di pameran UMKM binaan BI di Balai Kartini, Jakarta, Jumat (26/8/2016), dapat diidentifikasi ada 3 (tiga) kendala utama yang menghambat perkembangan industri kreatif di Indonesia, yaitu: (1) terbatasnya akses kredit yang dikarenakan para pelaku industri kreatif belum dapat mengelola laporan keuangan secara rapi, sehingga dalam perkembangannya, industri kreatif masih terhambat modal. (2) pelaku industri kreatif juga belum memiliki akses yang luas ke pasar internasional, hal ini disebabkan karena volume produksi yang belum mencapai batas minimum ketentuan impor. (3) terbatasnya SDM dan keterampilan, hal ini disebabkan karena karena pelaku industri kreatif tidak memiliki divisi khusus riset dan pengembangan, sehingga proses produksinya masih menggunakan cara tradisional (finance.detik.com, 2016).

Kota Pekalongan yang merupakan anggota jejaring Kota Kreatif Dunia UNESCO harus memiliki komitmen kuat untuk mempertahankan predikat tersebut. Beberapa cara telah dilakukan, salah satu di antaranya adalah dengan memberikan kemudahan kemudahan dalam mengakses informasi, melakukan komunikasi dan mendapatkan edukasi tentang berbagai hal yang mampu menguatkan daya saingnya. Salah satu solusi 
yang dapat diterapkan yaitu dengan membangun media komunikasi-informasi-edukasi (KIE) yang dapat diakses oleh para pelaku, pendidik, dosen, dan masyarakat industri kreatif.

Oleh karena itu, maka tujuan dari penelitian ini adalah terciptanya aplikasi komunikasi-informasi-edukasi (KIE) yang sesuai dengan kebutuhan penggunanya. Dengan adanya media tersebut diharapkan dapat meningkatkan daya saing pelaku industri kreatif Kota Pekalongan di era industry 4.0.

\section{TINJAUAN PUSTAKA}

\subsection{Kajian Teoritis}

\subsubsection{Media Komunikasi}

Media berasal dari kata medium yang merupakan bahasa latin. Secara harfiah arti dari kata medium adalah perantara, penyampai, atau penyalur. Beberapa para ahli telah memberikan batasan-batasan dari pengertian media. (1) Media merupakan teknologi pembawa pesan yang digunakan untuk keperluan instruksional, (2) media merupakan sarana komunikasi yang berbentuk cetak atau pandang dengar, termasuk teknologi perangkat kerasnya, (2) media merupakan sarana fisik untuk menyampaikan materi pengajaran seperti buku, film, video, slide dan komputer (Batubara, 2011).

\subsubsection{Metodologi Pengembangan Sistem Waterfall}

Metode pengembangan ini menggunakan pendekatan pengembangan secara sekuen dan sistematik yang dimulai dari level analisa sampai dengan level pemeliharaan (Jogiyanto, 2005). Model ini merupakan model yang paling lama dan paling banyak digunakan, berikut akan dijelaskan aktivitasaktivitas yang ada di setiap tahapan, yaitu:

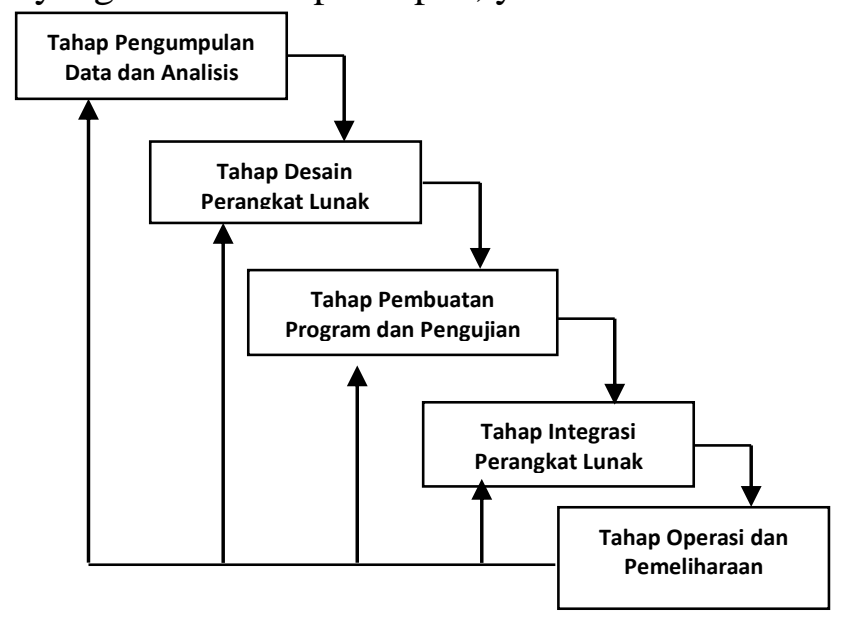

Gambar 1 Metode Pengembangan Sistem Waterfall

a) Tahap pengumpulan data dan analisis

Untuk memahami permasalahan serta kebutuhan dari pemakai maka analis harus memahami terlebih dahulu domain informasi, tingkah laku, unjuk kerja, dan antarmuka (interface) yang diperlukan oleh pemakai melalui berbagai data yang telah berhasil dikumpulkan dan didokumentasikan. 
b) Tahap desain perangkat lunak

Tahap ini adalah tahap menerjemahkan syarat/kebutuhan pemakai ke dalam sebuah representasi desain perangkat lunak yang selanjutkan dapat dikonversi ke dalam suatu bahasa pemrograman tertentu.

c) Tahap pembuatan program dan pengujian

Tahap ini merupakan tahap menterjemahkan desain ke dalam suatu bahasa pemrograman. Jika proses penterjemahan tersebut sudah selesai maka dilanjutkan ke proses pengujian untuk memastikan bahwa semua logika yang ada sudah teruji dengan baik serta untuk menemukan kesalahan-kesalahan dan memastikan bahwa sistem mampu memberikan hasil yang sesuai dengan kebutuhan.

d) Tahap integrasi system

Tahap ini merupakan tahap implementasi perangkat lunak ke keadaan sebenarnya.

e) Tahap operasi dan pemeliharaan

Perangkat lunak yang sudah diterapkan tersebut, masih dimungkinkan mengalami perubahan-perubahan seiring dengan perkembangan yang terjadi. Untuk itu perangkat lunak harus bisa menyesuaikannya, namun jika ternyata perubahan yang terjadi sudah tidak bisa diakomodasi lagi maka dapat dikembangkan perangkat lunak yang baru.

\subsection{Penelitian Terkait}

Tabel 1 Penelitian Terkait

\begin{tabular}{|c|c|c|c|c|}
\hline No & Judul & Penulis & Jurnal/Tahun & Kesimpulan \\
\hline 1. & $\begin{array}{l}\text { Meningkatkan daya saing UMKM batik Kota } \\
\text { Pekalongan dalam menghadapi era Masyarakat } \\
\text { Ekonomi ASEAN melalui pembangunan pusat } \\
\text { informasi berbasis WEB yang megintegrasikan } \\
\text { UMKM batik dengan masyarakat umum, kalangan } \\
\text { Perbankan, kalangan Akademik, KADIN dan } \\
\text { Pemerintah Kota Pekalongan. }\end{array}$ & $\begin{array}{l}\text { Christianto, Paminto } \\
\text { Agung; Susanto, } \\
\text { Eko Budi; } \\
\text { Kurniawan, Faisal }\end{array}$ & $\begin{array}{l}\text { Jurnal Litbang } \\
\text { Kota Pekalongan } \\
\text { ISSN 2085-0689, } \\
\text { Vol.8 No.1 Tahun } \\
2015\end{array}$ & $\begin{array}{l}\text { Walaupun banyak manfaat } \\
\text { yang didapatkan, namun } \\
\text { pusat informasi UMKM } \\
\text { batik Pekalongan tersebut, } \\
\text { baru pada tahap prototipe } \\
\text { dengan ruang lingkup hanya } \\
\text { pada UMKM batik. }\end{array}$ \\
\hline 2. & $\begin{array}{l}\text { Penguatan citra Pekalongan sebagai Kota Batik } \\
\text { melalui pembangunan pusat informasi UMKM batik } \\
\text { berbasis mobile yang mampu meningkatkan daya } \\
\text { saing UMKM batik dalam menghadapi persaingan era } \\
\text { Masyarakat Ekonomi ASEAN }\end{array}$ & $\begin{array}{l}\text { Christianto, Paminto } \\
\text { Agung; Susanto, } \\
\text { Eko Budi; } \\
\text { Kurniawan, Faisal }\end{array}$ & $\begin{array}{l}\text { Jurnal Litbang } \\
\text { Kota Pekalongan }\end{array}$ & $\begin{array}{l}\text { Walaupun banyak manfaat } \\
\text { yang didapatkan, namun } \\
\text { pusat informasi UMKM } \\
\text { batik Jawa Tengah tersebut, } \\
\text { baru pada tahap prototipe } \\
\text { dengan ruang lingkup hanya } \\
\text { pada UMKM batik di Jawa } \\
\text { Tengah }\end{array}$ \\
\hline 3. & $\begin{array}{l}\text { Mensinergikan lembaga pemerintahan, lembaga } \\
\text { keuangan dan lembaga riset dalam satu media } \\
\text { komunikasi untuk menguatkan daya saing UKM } \\
\text { kabupaten Batang }\end{array}$ & $\begin{array}{l}\text { Prasetiono, Slamet } \\
\text { Joko; Christianto, } \\
\text { Paminto Agung; } \\
\text { Susanto, Eko Budi }\end{array}$ & $\begin{array}{l}\text { Jurnal Riset, } \\
\text { Inovasi dan } \\
\text { Teknologi } \\
\text { Kabupaten } \\
\text { Batang, Vol } 1 \text { No } \\
2 \text { (2017), Terbit } \\
30 \text { Aug 2017, Hal } \\
9 \text { s.d.20 }\end{array}$ & $\begin{array}{l}\text { Walaupun banyak manfaat } \\
\text { yang didapatkan, namun } \\
\text { pusat informasi UKM } \\
\text { kabupaten Batang, baru pada } \\
\text { tahap desain dengan ruang } \\
\text { lingkup adalah seluruh UKM } \\
\text { binaan kabupaten Batang. }\end{array}$ \\
\hline 4. & $\begin{array}{l}\text { Identifikasi aplikasi e-Komunitas Industri Kreatif } \\
\text { Sektor Kerajinan Dekranasda Kota Bogor }\end{array}$ & Yan Andriariza & $\begin{array}{l}\text { Jurnal Penelitian } \\
\text { Pos dan } \\
\text { Informatika, e- } \\
\text { ISSN: 2476-9266 } \\
\text { p-ISSN: 2088- } \\
\text { 9402, JPPI Vol } 6 \\
\text { No } 1 \text { (2016) } 93 \text { - } \\
108\end{array}$ & $\begin{array}{l}\text { Aplikasi e-Komunitas dibuat } \\
\text { untuk memenuhi kebutuhan } \\
\text { pelaku industri kreatif namun } \\
\text { belum mensinergikan dengan } \\
\text { berbagai instansi terkait. }\end{array}$ \\
\hline 5. & $\begin{array}{l}\text { Pemetaan industri kreatif berbasis sistem informasi } \\
\text { geografis }\end{array}$ & $\begin{array}{l}\text { Darsin, Tutik } \\
\text { Khotimah }\end{array}$ & $\begin{array}{l}\text { Jurnal } \\
\text { DISPROTEK, } \\
\text { Volume } 7 \text { no. } 2 \\
\text { Juli } 2016 \\
\end{array}$ & $\begin{array}{l}\text { Sistem tersebut baru berupa } \\
\text { prototipe dan berfokus hanya } \\
\text { pada pemetaan industri } \\
\text { kreatif. }\end{array}$ \\
\hline
\end{tabular}




\section{METODE PENELITIAN}

\subsection{Metode Pengumpulan data}

Merupakan pengumpulan bahan baku untuk memberikan gambaran spesifik mengenai obyek penelitian dengan menggunakan beberapa teknik berikut ini:

a) Teknik Studi Literatur

Data diperoleh melalui beberapa referensi/jurnal yang terkait.

b) Teknik Wawancara

Data diperoleh dari hasil wawancara dengan narasumber yang terkait.

c) Teknik Penyebaran Kuisioner

Data diperoleh dari hasil rekapitulasi kuisioner yang disebarkan ke responden yang terkait.

\subsection{Analisis Kebutuhan}

Dari data yang sudah terkumpul, dilakukan identifikasi permasalahan beserta kebutuhan-kebutuhan yang harus dipenuhi, baik kebutuhan fungsional maupun kebutuhan non fungsional dari sistem yang akan dibangun dan merangkumnya kedalam sebuah solusi.

\subsection{Desain Sistem}

Dari solusi yang dihasilkan akan dilanjutkan dengan membuat desain konseptual dan detail desain dari sistem yang akan dibangun.

\subsection{Pembangunan Sistem}

Tahap akhir di tahun pertama adalah menterjemahkan desain tersebut dengan menggunakan bahasa pemrograman untuk menghasilkan aplikasi.

\section{HASIL DAN PEMBAHASAN}

\subsection{Pengumpulan Data}

Pengumpulan data dilakukan untuk mengetahui kebutuhan fungsional dan non fungsional sistem. Beberapa teknik yang dilakukan dalam pengumpulan data antara lain:

\subsubsection{Wawancara}

Dalam memperoleh data penelitian, peneliti telah melakukan wawancara kepada kepada dua narasumber yaitu Bapak Mujiono selaku ketua Pekalongan Creative City Forum (PCCF) Kota Pekalongan dan Bapak Victorianus selaku salah satu Pelaku Industri Kreatif Kota Pekalongan. Wawancara pertama kepada Ketua PCCF untuk mengetahui peran PCCF dalam memberikan informasi, pelatihan dan pendampingan kepada pelaku industri kreatif yang ada di Kota Pekalongan. Dari hasil wawancara yang telah dilakukan, dapat disimpulkan bahwa PCCF dalam melaksanakan tugas dan tanggung jawabnya dirasa kurang optimal dikarenakan kesulitan untuk berkomunikasi ke semua pelaku industri kreatif yang ada di Kota Pekalongan. Oleh karena itu PCCF memerlukan suatu media yang dapat digunakan untuk berkomunikasi dengan cepat, melakukan diskusi, dan memberikan informasi dengan cepat kepada pelaku industri kreatif.

Wawancara selanjutnya dilakukan kepada Bapak Victorianus sebagai salah satu pelaku industri kreatif di Kota Pekalongan. Dari hasil wawancara dengan Bapak Victorianus, dapat disimpulkan bahwa bapak 
Victorianus tidak mengetahui adanya informasi yang diberikan dari Pemerintah Kota Pekalongan, Bapak Victorianus juga kesulitan untuk melakukan komunikasi dengan Pemerintah Kota Pekalongan karena tidak mengetahui adanya media untuk berkomunikasi.

\subsubsection{Kuesioner}

Untuk mengetahui permasalahan yang dihadapi oleh pelaku industri kreatif, peneliti menggunakan kuesioner. Dalam hal ini peneliti menggunakan google form untuk mempersingkat waktu dalam pengumpulan data karena jumlah reponden yang banyak dan jarak yang jauh. Kuesioner yang menggunakan google form telah disebarkan kepada pelaku industri kreatif yang ada di Kota Pekalongan mulai tanggal 30 September 2019 sampai 10 Oktober 2019.

Dari hasil kuesioner yang diperoleh, dapat disimpulkan bahwa pemerintah sudah memberikan informasi yang bermanfaat kepada pelaku industri kreatif yang ada di Kota Pekalongan, akan tetapi informasi itu masih banyak yang belum diketahui oleh pelaku industri kreatif, hal ini dapat dilihat dari hasil kuesioner ada sebanyak 55 orang atau $82 \%$ belum mengetahui informasi yang diberikan oleh Pemerintah Kota Pekalongan. Data kuesioner dapat dilihat pada Tabel 2.

Tabel 2 Data Kuesioner

\begin{tabular}{|c|c|c|c|c|}
\hline No & Pertanyaan & $\begin{array}{l}\text { Jumlah } \\
\text { Ya }\end{array}$ & $\begin{array}{c}\text { Jumlah } \\
\text { Tidak }\end{array}$ & Total \\
\hline 1. & $\begin{array}{l}\text { Apakah Pemerintah Kota Pekalongan mempunyai program kerja dalam memberikan } \\
\text { informasi tertentu kepada pelaku industri kreatif? }\end{array}$ & 37 & 30 & 67 \\
\hline 2 & Apakah Pemerintah Kota Pekalongan mensosialisasikan informasi tersebut? & 27 & 40 & 67 \\
\hline 3 & Apakah anda mengetahui informasi tersebut? & 12 & 55 & 67 \\
\hline 4 & $\begin{array}{l}\text { Apakah Pemerintah Kota Pekalongan menyediakan media untuk berkomunikasi } \\
\text { dengan pelaku industri kreatif? }\end{array}$ & 27 & 40 & 67 \\
\hline 5 & Apakah anda mengetahui media tersebut? & 13 & 54 & 67 \\
\hline 6 & $\begin{array}{l}\text { Apakah Pemerintah Kota Pekalongan memberikan informasi pelatihan yang } \\
\text { bermanfaat bagi pelaku industri kreatif? }\end{array}$ & 44 & 23 & 67 \\
\hline 7 & $\begin{array}{l}\text { Apakah anda mengetahui informasi (pelatihan) yang diberikan Pemerintah Kota } \\
\text { Pekalongan }\end{array}$ & 24 & 43 & 67 \\
\hline 8 & $\begin{array}{l}\text { Apakah Pemerintah Kota Pekalongan memberikan informasi mengenai perbankan } \\
\text { atau permodalan untuk pembiayaan usaha? }\end{array}$ & 33 & 34 & 67 \\
\hline 9 & $\begin{array}{l}\text { Apakah anda mengetahui informasi (perbankan atau permodalan) yang diberikan } \\
\text { Pemerintah Kota Pekalongan? }\end{array}$ & 15 & 52 & 67 \\
\hline 10 & $\begin{array}{l}\text { Apakah anda setuju jika dibuatkan aplikasi berbasis android untuk mempermudah } \\
\text { melakukan komunikasi dengan Pemerintah Kota Pekalongan yang bisa diakses } \\
\text { dimanapun dan kapanpun? }\end{array}$ & 65 & 2 & 67 \\
\hline 11 & $\begin{array}{l}\text { Apakah anda setuju jika diberikan informasi pelatihan untuk menunjang } \\
\text { keterampilan pelaku industri kreatif dalam aplikasi tersebut? }\end{array}$ & 65 & 2 & 67 \\
\hline 12 & $\begin{array}{l}\text { Apakah anda setuju jika diberikan informasi permodalan untuk pembiayaan usaha } \\
\text { dalam aplikasi tersebut? }\end{array}$ & 67 & 0 & 67 \\
\hline
\end{tabular}

\subsubsection{Analisa Kebutuhan Sistem}

Dari hasil pengumpulan data yang telah dilakukan, maka didapatkan hasil bahwa pemerintah yang dalam hal ini adalah PCCF kesulitan untuk melakukan komunikasi dengan pelaku industri kreatif yang ada di Kota Pekalongan. Di sisi lain, pelaku industri kreatif juga mengalami kendala untuk berkomunikasi dengan pemerintah. Sebagai solusinya, maka diperlukan suatu media yang dapat menyediakan komunikasi yang mudah, cepat dan dapat diakses di manapun dan kapanpun. Fungsi-fungsi yang 
diperlukan dalam aplikasi ini dijabarkan pada kebutuhan fungsional dan nonfungsional sistem yang akan dibuat.

Kebutuhan fungsional sistem yang akan dibuat di antaranya sistem dapat memberikan informasi (berita / pengumuman) yang bermanfaat bagi pelaku industri kreatif, dapat menyediakan diskusi (chat) antara Pemerintah Kota Pekalongan, perbankan dengan pelaku industri kreatif, dapat memberikan edukasi (bisa bentuk file, foto atau video) untuk peningkatan keterampilan bagi pelaku industri kreatif dan dapat memberikan informasi permodalan (user admin, pemerintah dan perbankan) kepada user pelaku industri kreatif.

Kebutuhan nonfungsional dari sistem yang akan dibuat yaitu sistem dapat dijalankan pada perangkat android minimal versi android 4.0.3 (ICS), dapat memastikan bahwa data yang digunakan dalam sistem harus terlindung dari akses yang tidak berwenang, sistem memiliki tampilan (antar muka) yang mudah dipahami.

\subsection{Desain}

4.2.1 Desain Alur Sistem

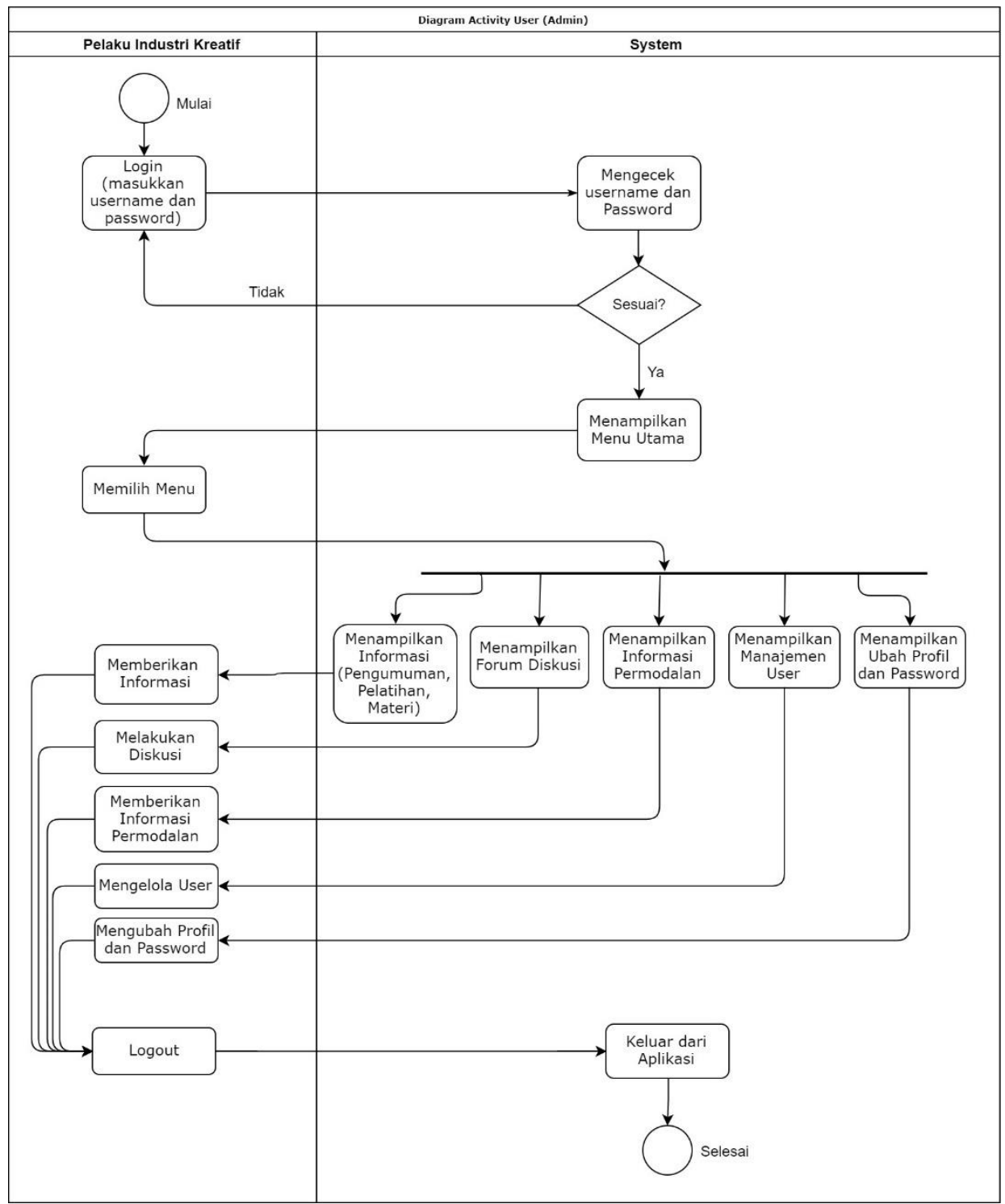

Gambar 2 Alur Sistem yang Diusulkan 
Gambar 5 Merupakan tampilan antarmuka login yang digunakan untuk masuk ke sistem. User memasukkan username yang berupa email dan password. Sistem akan mendeteksi level pengguna sesuai username yang diinput dan akan menampilkan Menu Utama. Menu yang ditampilkan juga akan disesuaikan dengan level pengguna.

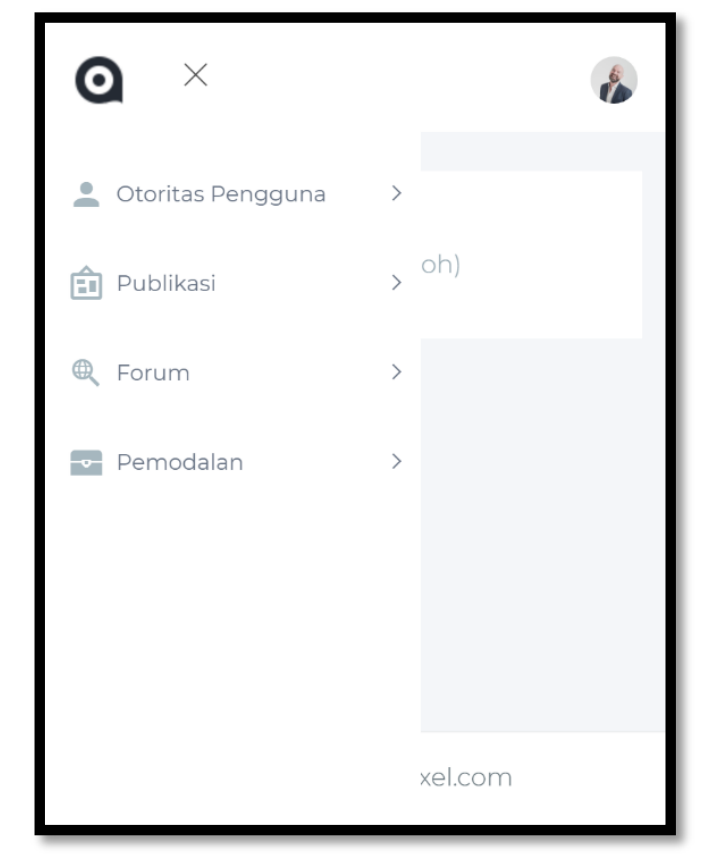

Gambar 6 Tampilan Menu Utama pada Admin

Gambar 6 Merupakan tampilan antarmuka Menu Utama pada admin. Di dalam menu utama terdapat beberapa menu yang dapat dipilih yaitu otoritas pengguna, publikasi, forum dan permodalan.

\subsection{Pembangunan}

Pembangunan sistem menggunakan bahasa pemrograman berbasis web, seperti: javascitpt, framework bootstrap, framework codeigneter, JSON (JavaScript Object Notation). Untuk pembangunan aplikasi android menggunakan Phonegap.

\subsection{Pengujian}

Pengujian sistem dilakukan dengan menggunakan User Acceptance Test (UAT). UAT merupakan proses pengujian yang dilakukan oleh pengguna dengan hasil output sebuah dokumen hasil uji yang dapat dijadikan bukti bahwa software sudah diterima dan sudah memenuhi kebutuhan yang diminta. Proses pengujian UAT dilakukan kepada bapak Rizki sebagai salah satu user pelaku industri kreatif.

Dari hasil pengujian di atas, dapat disimpulkan bahwa aplikasi yang dibangun sudah memiliki fitur yang lengkap sesuai dengan yang diharapkan. Aplikasi ini juga mudah dipahami dalam penggunaanya, meskipun untuk pengunaan pertama kali butuh waktu untuk memahaminya. Pelaku industri kreatif dapat mengetahui informasi tentang berita, pengumuman, materi dan permodalan dengan cepat dari aplikasi ini. Pelaku industri kreatif juga dapat melakukan diskusi atau tanya jawab dengan Pemerintah Kota Pekalongan dengan aplikasi ini. 


\section{KESIMPULAN DAN SARAN}

\subsection{Simpulan}

Dari hasil pengujian aplikasi yang dilakukan dapat disimpulkan bahwa Media Komunikasi-Informasi-Edukasi(KIE) Industri Kreatif telah sesuai dengan kebutuhan fungsional dan non fungsional yang diharapkan.

Aplikasi ini dapat mempermudah Pemerintah Kota Pekalongan dalam memberikan informasi berita atau pengumuman langsung kepada pelaku industri kreatif di Kota Pekalongan, sehingga pelaku industri kreatif bisa mengetahui informasi yang diberikan dengan lebih cepat. Pemerintah Kota Pekalongan juga dapat memberikan materi yang bermanfaat kepada pelaku industri kreatif di Kota Pekalongan, sehingga pelaku industri kreatif dapat meningkatkan pengetahuan sesuai dengan bidangnya. Selain itu juga Pemerintah Kota Pekalongan dapat memberikan informasi pelatihan atau workshop kepada pelaku industri kreatif Kota Pekalongan untuk peningkatan keterampilan pelaku industri kreatif. Pemerintah Kota Pekalongan dan Perbankan juga dapat memberikan informasi permodalan langsung kepada pelaku industri kreatif di Kota Pekalongan untuk peningkatan usahanya..

Bagi Pelaku Industri Kreatif, aplikasi ini dapat mempermudah melakukan diskusi dengan Pemerintah Kota Pekalongan dalam forum yang disediakan aplikasi dan juga mendapatkan informasi pelatihan dan permodalan.

\subsection{Saran}

Aplikasi ini hanya ditujukan untuk pelaku industri kreatif, ke depannya bisa diperluas untuk jenis industri yang lain. Aplikasi ini dikembangkan dengan jenis hybrid yang memiliki performa kurang bagus, untuk pengembangan selanjutnya bisa dikembangkan dengan native yang memiliki performa yang lebih baik. Keamanan aplikasi ini hanya menggunakan user dan password yang mungkin bisa diretas, untuk lebih aman perlu ditingkatkan lagi dari segi keamanannya. Untuk pengembangan selanjutnya, bisa ditambahkan notifikasi, pesan dan lain-lain untuk mempermudah pengguna dalam menggunakan aplikasi.

\section{DAFTAR PUSTAKA}

Andriariza, Y. (2016). Identifikasi aplikasi e-Komunitas Industri Kreatif Sektor Kerajinan Dekranasda kota Bogor. Jurnal Penelitian Pos dan Informatika, e-ISSN: 2476-9266 p-ISSN: 2088-9402, JPPI Vol 6 No 1 (2016), 93 - 108.

Batubara, A. K. (2011). Diktat Media Komunikasi. Medan, Indonesia: Fakultas Dakwah Institut Agama Islam Negeri Medan Sumatra Utara.

Christianto, P. A., Susanto, E. B., \& Kurniawan, F. (2015). Meningkatkan daya saing UMKM batik Kota Pekalongan dalam menghadapi era Masyarakat Ekonomi ASEAN melalui pembangunan pusat informasi berbasis WEB yang megintegrasikan UMKM batik dengan masyarakat umum, kalangan Perbankan, kalangan Akademik, KADIN dan Peme. Jurnal Litbang Kota Pekalongan (ISSN 2085-0689) Vol. 8 No. 1 Tahun 2015.

Christianto, P. A., Susanto, E. B., \& Kurniawan, F. (2016). Penguatan citra Pekalongan sebagai kota batik melalui pembangunan pusat informasi UMKM batik berbasis mobile yang mampu 
meningkatkan daya saing UMKM batik dalam menghadapi persaingan era Masyarakat Ekonomi ASEAN. Jurnal Litbang Kota Pekalongan ISSN 2085-0689 (media cetak) ISSN 2503-0728 (media online) Vol. 11, No. 1 Tahun 2016.

Darsin, \& Khotimah, T. (2016). Pemetaan industri kreatif berbasis sistem informasi geografis. Jurnal DISPROTEK, Volume 7 no. 2 Juli 2016.

finance.detik.com. (2016). https://finance.detik.com/berita-ekonomi-bisnis/d-3284282/ini-kendalayang-dihadapi-pelaku-industri-kreatif. diakses 27 Maret 2019.

Jogiyanto, H. (2005). Analisis dan Desain Sistem Informasi. Yogyakarta: Andi Offset.

Pemerintah Republik Indonesia. (2015). Peraturan Presiden Republik Indonesia Nomor 6 Tahun 2015 Tentang Badan Ekonomi Kreatif. Jakarta: Sekretariat Negara Republik Indonesia.

Prasetiono, S. J., Christianto, P. A., \& Susanto, E. B. (2017). Mensinergikan lembaga pemerintahan, lembaga keuangan dan lembaga riset dalam satu media komunikasi untuk menguatkan daya saing UKM kabupaten Batang. Jurnal Riset, Inovasi dan Teknologi Kabupaten Batang Vol 1 No 2 (2017), Terbit 30 Aug 2017, 9-20.

Thomas, Dianto G., Sherwin R. U. A. Sompie, dan Brave A. Sugiarso. "Virtual Tour Sebagai Media Promosi Interaktif Penginapan Di Kepulauan Bunaken.” E-Journal Teknik Informatika Vol. 13, No. 1 (2018) ISSN : 2301-8364, 2018.

Vaughan, Tay. Multimedia : Making it Work. Edisik ke 6. Yogyakarta: Andi Offset, 2004. 